DOI: 10.22616/REEP.2019.001

\title{
Towards Media Literacy in the Education Curriculum: Experience of Latvia
}

\author{
Rudite Andersone $^{1}$ Dr. paed.; Ineta Helmane ${ }^{2}$ Dr. paed. \\ University of Latvia, Latvia \\ rudite.andersone@lu.lv'; ineta.helmane@gmail.com²
}

\begin{abstract}
Media literacy is important for life in the changing world. Media literacy is the ability to access, analyse, evaluate and communicate information in a variety of forms as well as the ability of individuals to access and understand information through different media tools and platforms, such as television, radio, print media, the Internet and digital technology. The aim of the paper is to analyse the planning of developing the media literacy in the basic education curriculum in Latvia. The study, using the document analysis, has selected the basic education curricula in the new education content project Competencebased approach in the teaching/learning content School 2030 in the following areas: Technologies, Social and civic area, Sciences area. Such criteria as the skill to find the information in the digital environment; the skills to analyse the obtained information; the skill to evaluate the credibility of the information were chosen in the research aspect of developing the media literacy. The study concludes that the skill to find information in different sources and the skill to analyse the found information are purposefully developed in the expected learning outcomes. The development of the skills of evaluating the credibility of the found information, however, needs more attention.
\end{abstract}

Keywords: basic education, curriculum, media literacy.

\section{Introduction}

New economic realities and rapid shifts in labour markets are fundamentally changing education systems around the world; and now, access to high quality education institutions at all levels is globalizing as well (Jolls, 2014). This change movement toward being a global information economy and having education systems to match are persistent and demand attention, experimentation, and investment (Jolls, 2015).

As a consequence of the change in the meaning attributed to literacy, the competencies that literate individuals need to possess are being redefined. The competencies of literate people nowadays include the ability of analysing critically messages of different types, such as texts, images, and audio files, videos in multidirectional and multidimensional information and communication channels, and creating texts in different forms. Moreover, in this new period, the problem of accessing information has been dissolved thanks to the opportunities offered by ICTs. In contrast, avoidance skills to abstain from information sources (Bawden, Robinson, 2009) that are constructed, harmful and unreal (Potter, 2008) are regarded among the literacy skills. Today, information and knowledge are often considered to be the most strategically important resources, and learning - the most strategically important capability, for any individual, community, or the entire nation. Despite the fact that access to information and knowledge has increased during the last decade due to the higher levels of basic literacy in many countries around the world, significant challenges and obstacles still remain. It is still not obvious how to create a favourable environment for learning, or how to nurture the capabilities of citizens (Global Media and..., 2013). An individual today needs to possess the following competencies: recognizing and expressing facts, making use of texts of different types to express one's emotions and thoughts, reflecting on the obtained knowledge and relating it to one's own behaviours, knowing the form of texts shared in different sources and re-creating and using them, possessing up-to-date knowledge and skills, communicating effectively, building one's capacity to be able to provide cultural and social contribution, expressing oneself through using one's knowledge and skills in social and cultural field (Kellner, Share, 2005; Ayres, Langone, Douglas, 2009; Bahadin, Cahit, 2017).

Media literacy is understood as the ability to access, analyse, evaluate and communicate messages in a variety of forms (Aufderheide, 1993; Bahadin, Cahit, 2017) as well as the ability of individuals to access and understand information through different means, such as television, radio, print media, the Internet and digital technology (Silver, 2009). The core of media literacy includes a wider variety of aims, goals and intentions, including the ability to create messages, reflect on media influence and consider the social responsibilities of being an effective communicator, and use the power of information and 
communication to take appropriate forms of personal, social and political action (Hobbs, 2010; Hobbs, Tuzel, 2017). Thus, media literacy includes four main skills to be an effective media literate - access, analyse, evaluate and communicate (Aufderheide, 1993; Hobbs, 2001; Livingstone, 2003; Jolls, 2008; Silver, 2009; Schmidt, 2013; Silverblatt, 2014), as well as using media tools and platforms effectively (Potter, 2009; Bahadin, Cahit, 2017). Media constitutes the whole range of modern communications television, cinema, video, radio, Internet, music, magazines, and games - and media texts are the programs, films, images, websites, and more consumed by mass audiences (Buckingham, 2003; Harshman, 2017). Media literacy can be regarded as an umbrella term independent of the variables such as media tools at use, technology and so on. Besides, the unprecedented developments and increasing variety in ICT have had a significant role in the emergence of new forms of literacy such as new media literacy and social media literacy (Walsh, 2010).

As media literacy is understood as the right of all citizens (Area, 2012; Fedorov, Levitskaya, Camarero, 2016), then efforts should be made conducive to digital inclusion to ensure access to new technologies, implementing and promoting standards and accessibility guidelines through the implementation of training courses and media education (Garcia-Murillo, MacInnes, 2002). This assumption is based on the curriculum that is able to evaluate the use of technology and knowledge of the media, supported by psychoeducational theories that encourage young people and the general public to use them positively. It is also based on the personal contribution of those who can improve society through their moral values (Camarero, Cuadrado, Herrero-Diz, 2015; Fedorov, Levitskaya, Camarero, 2016).

The framework of the curriculum of media literacy education is based on the following approaches: Enhancing consumer awareness, Critical thinking, Considering the role of citizenship, Ontology, Value, Semiotic, Cultural studies, Synthetic creative, Cross disciplinary approaches (Andersen, Duncan, Pungente, 1999). Media literacy has many benefits in the teaching /learning process. For instance, media literacy engages students - bringing the world of media into the classroom connects learning with "real life" and validates their media culture as a rich environment for learning and gives students and teachers alike a common approach to critical thinking that, when internalized, becomes the second nature for life. It provides an opportunity for integrating all subject areas, increases the ability and proficiency of students to communicate (express) and disseminate their thoughts and ideas in a wide (and growing) range of print and electronic media forms - and even international venues (Jolls, 2015).

As it has been concluded in the UNESCO study on media literacy, then only fifty percent of 9-12-yearolds and adolescents (13-16 years) - eighty percent think they can compare different internet websites and websites to understand whether the information in them is true. Some children and adolescents lack the knowledge and skills necessary to use, create and share various types of information safely and skilfully (Petijums par 9..., 2017), thus there exists a challenge for the Curriculum developers to give the students an opportunity to understand and use the Internet or the possibilities offered by ICT in the implementation of a meaningful teaching/learning process.

The aim of the paper is to analyse the planning of the development of media literacy in the basic education curriculum in the Latvia.

\section{Methodology}

The study, using the document analysis, has selected the basic education curricula in the new education content project Competence-based approach in the teaching/learning content School 2030 (Skola 2030, 2017) in the following areas: Technologies, Social and civic area, as well as the Sciences area, which in the theoretical study were noted as being the most important in the development of media literacy. Such criteria as the skill to find the information in the digital environment; the skills to analyse the obtained information; the skill to evaluate the credibility of the information were used in the theoretical study.

\section{Results and Discussions}

As the content of the Social and civic area is closely connected with each individual's abilities to understand the society and the processes happening in it as well as the skill to join and participate in it therefore such crucial media literacy skills as the skill to access, analyse, evaluate and communicate should be definitely emphasised. 
For instance, when acquiring social sciences and history in basic school, the student forms his/her historical and civic awareness as well as stable social habits in communication and interaction with peers. The student develops and explains the personal "I" observing and participating in the social environment of the local community; make decisions that are significant to oneself and others in the everyday situations; explores economic, political and social problems that are important for Latvia as a state and the society in the context of present and the past; participates in the social processes and evaluates the consequences of one's actions (Skola 2030, 2017).

Table 1

Planned learning outcomes in the Social and civic content area

\begin{tabular}{|c|c|c|c|}
\hline \multicolumn{4}{|c|}{ Social and civic content area } \\
\hline & $\begin{array}{c}\text { The skill to find information in the digital } \\
\text { environment }\end{array}$ & $\begin{array}{l}\text { The skill to analyse the } \\
\text { obtained information }\end{array}$ & $\begin{array}{l}\text { The skill to evaluate } \\
\text { the credibility of the } \\
\text { information }\end{array}$ \\
\hline 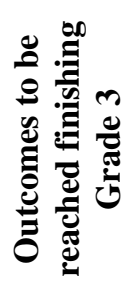 & $\begin{array}{l}\text { Obtains information from diverse sources of } \\
\text { information about social groups that are } \\
\text { represented in the closest community (family, } \\
\text { class, school, church parish, etc.) in order to } \\
\text { conclude to which social groups the student } \\
\text { belongs }\end{array}$ & & \\
\hline \multirow{2}{*}{ 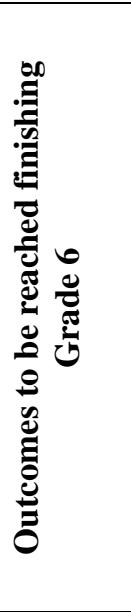 } & $\begin{array}{l}\text { Searches for examples in mass media } \\
\text { (newspapers, Internet news sites, etc.) and } \\
\text { literature about people's actions in different } \\
\text { everyday situations. } \\
\text { Searches for examples in the information } \\
\text { sources about Latvia's relations with } \\
\text { neighbouring countries... } \\
\text { Searches for examples in the information } \\
\text { sources about the expression of sponsoring } \\
\text { and charity in the society nowadays and in } \\
\text { the history... }\end{array}$ & $\begin{array}{l}\text { Analysing the } \\
\text { information available in } \\
\text { the home page of the } \\
\text { Enterprise and } \\
\text { municipality register } \\
\text { finds out which } \\
\text { enterprises and in which } \\
\text { spheres are functioning } \\
\text { in the local municipality. }\end{array}$ & \\
\hline & \multicolumn{2}{|c|}{$\begin{array}{l}\text { Obtains information from mass media about personalities the student } \\
\text { would like to resemble in order to conclude which character qualities, } \\
\text { knowledge and skills it possesses and substantiates his/her choice. } \\
\text { Obtains and analyses the examples discussed in mass media... }\end{array}$} & \\
\hline 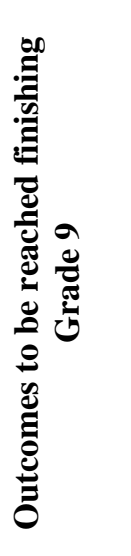 & $\begin{array}{l}\text { Using different sources of information, } \\
\text { different features in the countryside and towns. } \\
\text { Explores job vacancies, experts' opinions } \\
\text { conclude which knowledge and skills are need } \\
\text { Using different mass media, evaluates the } \\
\text { caused by technologies, cultural traditions } \\
\text { development of both Latvia and the whole hum } \\
\text { Compares the information found in differen } \\
\text { Seeks examples in virtual media,... } \\
\text { Using different sources of information (press, } \\
\text { etc.), plans and makes inquiries about the cultu } \\
\text { the region in order to prepare informative } \\
\text { organize visits to the memorial sites and to pre } \\
\text { sense of belonging to Latvia. }\end{array}$ & $\begin{array}{l}\text { akes out common and } \\
\text { a.o. sources in order to } \\
\text { ed in the labour market. } \\
\text { mpact of transformations } \\
\text { and social status on the } \\
\text { ankind... } \\
\text { mass media... } \\
\text { library, memoirs, archive, } \\
\text { cal and historical legacy of } \\
\text { naterials, popularize and } \\
\text { serve them improving the }\end{array}$ & $\begin{array}{l}\text { Using different mass } \\
\text { media, summarises } \\
\text { and groups different } \\
\text { opinions about } \\
\text { historical events of } \\
\text { Latvia in order to draw } \\
\text { conclusions based on } \\
\text { facts about the causes } \\
\text { of emerging } \\
\text { different/contradictory } \\
\text { opinions and the } \\
\text { credibility of } \\
\text { information sources. }\end{array}$ \\
\hline
\end{tabular}

Thus, the content of Social and civic area, its acquisition should be closely linked with the media literacy in which the focus is laid both on the skill to find information in the digital environment and to analyse the information about history and issues of civic awareness, about economic, political and social issues important to the state of Latvia and its society. The skill to find information in the digital environment is mainly emphasised and acquired in the context of media literacy finishing Grades 3,6 and 9 (Table 1). The observed tendency is that in each set of grades the acquisition of media literacy is gradually and successively broadened. For instance, finishing Grade 3 the possibility to master the skill of finding information in the digital environment is facilitated, finishing Grade 6 this skill is supplemented with 
the skill to analyse the obtained information and finishing Grade 9 the skill to evaluate the credibility of information is included in the content

In Sciences the student finds out the processes and phenomena in nature applying the inquiry skills. The link with the media literacy as the skill to find information in the digital environment, the skill to analyse the obtained information as well as the skill to evaluate the credibility of information are important in the inquiry action. It is indicated in the new teaching/learning content of the sciences area that applying the inquiry skills in different contexts the student learns to think as a scientist, acquires the experience of scientific thinking not only in the lessons but also making civilly responsible decisions in different life situations. Finishing the basic school, the student recognizes, offers and evaluates explanations about a definite set of natural phenomena; uses the inquiry skills in problem solving and performing small inquiries; analyses and evaluates data, expresses personal opinion and arguments in different ways and draws conclusions from data; acts responsibly for preserving the surrounding environment (Skola 2030, 2017).

The skill to find information in the digital environment is included in the science area in the context of media literacy. Despite the fact that the aim of the sciences area stresses the importance of analysing and evaluating the data, it is mainly understood as the evaluation of the data obtained in the inquiry process not the skill to analyse the information found in the digital environment. The skill to evaluate the credibility of information, in its turn, is envisaged for the Grades 7-9 (Table 2).

Table 2

Planned learning outcomes in the Sciences content area

\begin{tabular}{|c|c|c|}
\hline \multicolumn{3}{|c|}{ Sciences content area } \\
\hline & $\begin{array}{l}\text { The skill to find information in the digital } \\
\text { environment }\end{array}$ & $\begin{array}{c}\text { The skill to evaluate the credibility } \\
\text { of the information }\end{array}$ \\
\hline 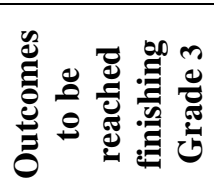 & $\begin{array}{l}\text { Under the teacher's guidance uses the information } \\
\text { sources (children's encyclopaedias, handbooks, } \\
\text { media). }\end{array}$ & \\
\hline 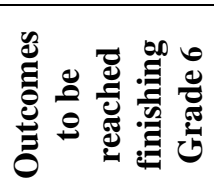 & $\begin{array}{l}\text { Uses information sources (encyclopaedias, plans, } \\
\text { maps, globe, instructions) applying a suitable } \\
\text { strategy. }\end{array}$ & \\
\hline 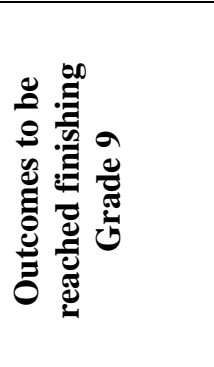 & $\begin{array}{l}\text { Uses information sources (periodic table of } \\
\text { chemical elements, deliquescence table, metal } \\
\text { activity range, scale of electromagnetic waves, map } \\
\text { of the star-lit sky, biological drawing, classification } \\
\text { schemes of living organisms, phylogenetic trees, } \\
\text { pyramid of gender age structure, climograph, geo- } \\
\text { chronological scale, soil profiles, satellite pictures, } \\
\text { aero photos, thematic maps), applying a suitable } \\
\text { strategy }\end{array}$ & $\begin{array}{l}\text { Gives arguments to one's opinions } \\
\text { using credible data from several } \\
\text { sources, models and topical science } \\
\text { theories that support or overturn the } \\
\text { explanation about natural phenomena } \\
\text { and processes. }\end{array}$ \\
\hline
\end{tabular}

In technologies area the student learns about different aspects how things (products) are created in the world, how they are made manually, using tools, equipment or automatically. During the basic school the student gains practical experience of the technologies' progress participating in the process of creating and implementing things (products) and digital solutions, learning to think and perform as a craftsman, designer, engineer, and programmer. Finishing the basic school, the student is able to make products that are personally needed or necessary for the community and offer digital solutions, designing and constructing, using different methods, tools and equipment, incl. digital, choosing the appropriate materials and design; has acquired practical experience of realizing a simple technological process and solving engineering and technical problems; is able to use safely, effectively and responsibly digital technologies for self-realization, communication, cooperation, participation; forms the habit to use resources purposefully and responsibly in practical work (Skola 2030, 2017).

During the initial stage of basic school students get acquainted with simple application programmes that are necessary for the acquisition of other school subjects. In Grades 4-6, students do practical projects 
and create simple products (things), models, objects and acquire different strategies, incl. digital, in the work with different materials. The new content in Technologies area pays special attention to digital literacy, its development and does not link it with media literacy. The skill to find information dominates in Technologies content area, but the skill to analyse the obtained information and the skill to evaluate the credibility of the found information are developed and improved minimally. For instance, the skill to find information in the digital environment dominates in the outcomes to be reached finishing Grade 3; no attention is paid to whether and how to analyse the found information and the skill to evaluate the credibility of information (Table 3 ).

Table 3

Planned learning outcomes in the Technologies content area

\begin{tabular}{|c|c|c|c|}
\hline \multicolumn{4}{|c|}{ Technologies content area } \\
\hline & $\begin{array}{l}\text { The skill to find information } \\
\text { in the digital environment }\end{array}$ & $\begin{array}{l}\text { The skill to analyse } \\
\text { the obtained } \\
\text { information }\end{array}$ & $\begin{array}{l}\text { The skill to evaluate the } \\
\text { credibility of the } \\
\text { information }\end{array}$ \\
\hline 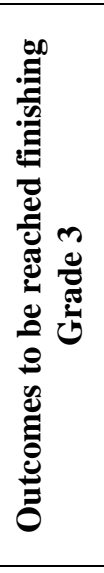 & $\begin{array}{l}\text { Opens the Internet site, uses } \\
\text { hyperlinks and in search engine } \\
\text { seeks the information according to } \\
\text { the given keyword. } \\
\text { Copies the text and picture from } \\
\text { the Internet site into another } \\
\text { document giving the references. } \\
\text { Uses some main functions of the } \\
\text { school management systems and } \\
\text { Internet learning sites, including } \\
\text { communication possibilities. } \\
\text { Mention consequences that can } \\
\text { appear downloading files and } \\
\text { opening sabotaging Internet sites }\end{array}$ & & \\
\hline 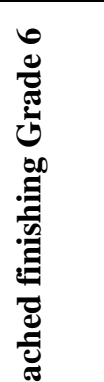 & \multicolumn{2}{|c|}{$\begin{array}{l}\text { Finds information about responsible design solutions in the } \\
\text { digital environment, analyses, structures information } \\
\text { according to given instructions, formulates and expresses } \\
\text { personal opinion about them, makes a survey in the Internet, } \\
\text { summarises the obtained information; } \\
\text { Uses responsibly several Internet services (e.g., World Wide } \\
\text { Web, Web browser, communication tools, and planner) in order } \\
\text { to find or share information, keeping the safety rules and } \\
\text { considering their advantages and disadvantages. }\end{array}$} & \\
\hline 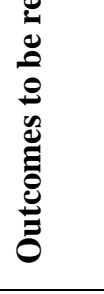 & $\begin{array}{l}\text { Uses IT for getting acquainted with } \\
\text { the cultural legacy of one's region } \\
\text { (town, municipality) and acquiring } \\
\text { other experience }\end{array}$ & & $\begin{array}{l}\text { Explains why the content of } \\
\text { the disseminated } \\
\text { information should be } \\
\text { evaluated, evaluates the } \\
\text { adequacy of the information } \\
\text { accessible in web pages to the } \\
\text { concrete target group. }\end{array}$ \\
\hline 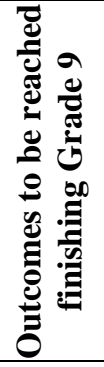 & & & $\begin{array}{l}\text { Gives features and ways of } \\
\text { cheating out (fishing) of } \\
\text { information, explains how to } \\
\text { escape from defrauding of } \\
\text { information. Is aware that } \\
\text { sometimes cyberspace can be } \\
\text { used as a means of } \\
\text { propagating cruelty and } \\
\text { violence. }\end{array}$ \\
\hline
\end{tabular}




\section{Conclusions}

Media literacy is important for the life in a changing world. Media literacy is understood as the ability to access, analyse, evaluate and communicate messages in a variety of forms as well as the ability of individuals to access and understand information through different means, such as television, radio, print media, the Internet and digital technology.

Media literacy is developed in the new basic education curriculum. The outcomes to be reached in Technologies, Sciences and Social and civic areas planned in the Curriculum, finishing Grade 6 the skills to find information in different sources and to analyse the found information are developed purposefully and their development continues until the end of Grade 9. However, the development of the skill to evaluate the credibility of information is little paid attention. Only some outcomes in each of the three content areas serve as evidence to this. Here the new basic education curriculum needs improvement.

\section{Bibliography}

1. Andersen N., Duncan B., Pungente J.J. (1999). Media Education in Canada-the Second Spring. In U. Carlson, C. Feilitzen (Eds.), Children and Media: Image. Education. Participation. Gothenburg: Nordicom + Nordic Council of Ministers + Swedish Ministry of Culture + University of Gothenburg.

2. Area M. (2012). Sociedad liquida, web 2.0 y alfabetizacion digital (Society, Web 2.0 and Digital Literacy). Aula de Innovacion Educativa, 212, 55-59 (in Spanish).

3. Aufderheide P. (1993). Media Literacy: A report of the national leadership conference on media literacy. Washington, DC: Aspen Institute.

4. Ayres K.M., Langone J., Douglas K. (2009). Technology, UDL and literacy activities for people with developmental delays. In L.T.W. Hin, R. Subramaniam (Eds.), Handbook of research on new media literacy at the K-12 level: issues and challenges. New York: IGI- Global.

5. Bahadin E., Cahit E. (2017). Development of a Media Literacy Skills Scale. Contemporary Educational Technology, 8(3), 249-267. Retrieved from https://files.eric.ed.gov/fulltext/EJ1148529.pdf

6. Bawden D., Robinson L. (2009). The dark side of information: overload, anxiety and other paradoxes and pathologies. Journal of Information Science, 35(2), 180-191.

7. Buckingham D. (2003). Media education: Literacy, learning, and contemporary culture. Cambridge, UK: Polity Press.

8. Camarero E., Cuadrado F.J., Herrero-Diz P. (2015). Media Literacy to young poor in Nicaragua. Working on a model of empowerment and employability for social change. First results. Russian Journal of History, Theory and Practice of Media Education. 45(2), 54-61. Retrieved from https://www.researchgate.net/publication/276830261_Media_Literacy_to_Young_Poor_in_Nicaragua _Working_on_a_Model_of_Empowerment_and_Employability_for_Social_Change_First_Results

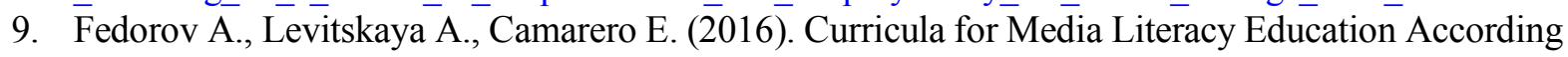
to International Experts. European Journal of Contemporary Education, 17(3), 324-334.

10. Garcia-Murillo M., MacInnes I., (2002). The impact of technological convergence on the regulation of ICT industries. The International Journal on Media Management 5(1), 57-67.

11. Global Media and Information Literacy Assessment Framework: Country Readiness and Competencies. (2013). Paris: United Nations Educational, Scientific and Cultural Organization (UNESCO). Retrieved from https://unesdoc.unesco.org/ark:/48223/pf0000224655

12. Harshman J. (2017). Developing Globally Minded, Critical Media Literacy Skills. Journal of Social Studies Education Research, 8(1), 69-92. Retrieved from https://files.eric.ed.gov/fulltext/EJ1141857.pdf

13. Hobbs R. (2001). The great media literacy debates in 2001. Community Media Review, 21, 1723.

14. Hobbs R. (2010). Digital and media literacy: a plan of action. Washington, DC: The Aspen Institute + the John L. + James S. Knight Foundation. Retrieved from https://www.knightfoundation.org/media/uploads/publication_pdfs/Digital_and_Media_Literacy A_Plan_of_Action.pdf

15. Hobbs R., Tüzel S. (2017). Teacher motivations for digital and media literacy. An examination of Turkish educators. British Journal of Educational Technology, 48(1), 7-22. 
16. Jolls T. (2014). The Global Media Literacy Imperative. The Russian-American Education Forum: An Online Forum, 6(1), Retrieved from http://www.rus-ameeduforum.com/content/en/?task=art\&article=1001036\&iid=18

17. Jolls T. (2015). The New Curricula: How Media Literacy Education Transforms Teaching and Learning. Journal of Media Literacy Education, 7(1), 65 -71.

18. Jolls T. (2008). Literacy for the 21st century: an overview and orientation guide to media literacy education. Center for Media Literacy. Retrieved from https://www.medialit.org/readingroom/literacy-21st-century-overview-orientation-guide-media-literacy-education

19. Kellner D., Share J. (2005). Toward critical media literacy: core concepts, debates, organizations and policy. Discourse: studies in the cultural politics of education, 26(3), 369-386. Retrieved from $\mathrm{http} / / / \mathrm{citeseerx}$.ist.psu.edu/viewdoc/download?doi=10.1.1.469.1475\&rep=rep1\&type=pdf

20. Livingstone S. (2003). The changing nature and uses of media literacy. Media@1se Electronic Working Papers 4. London, UK: London School of Economics and Political Science.

21. Potter W.J. (2008). Media Literacy. Thousand Oaks, CA: Sage Publications, Inc.

22. Potter W. J. (2009). Media literacy. In W.F. Eadie (Ed.), 21 st century communication, Thousand Oaks, CA: Sage Publications, Inc., 558-567.

23. Petijums par 9 lidz 16 gadus vecu bernu un pusaudzu medijpratibu Latvija (Research about Media Literacy of 9-16 years old pupils in Latvia). (2017). Riga: University of Latvia+ Ministry of Culture. (in Latvian)

24. Schmidt H.C. (2013). Media literacy education from kindergarten to college: A comparison of how media literacy is addressed across the educational system. Journal of Media Literacy Education, 5(1), 295-309. Retrieved from http://citeseerx.ist.psu.edu/viewdoc/download?doi=10.1.1.859.5631\&rep=rep1\&type=pdf

25. Silver A. (2009). A European approach to media literacy: moving toward an inclusive knowledge society. In D. Frau-Meigs, J. Torrent (Eds.), Mapping media education policies in the world: Visions, programmes and challenges, New York: UNAlliance of Civilizations, 11-13.

26. Silverblatt A. (Ed.). (2014). The Praeger Handbook of Media Literacy. Santa Barbara, California and Oxford, England: Praeger.

27. Skola 2030. (2017). Izglitiba musdienigai lietpratibai: macibu satura un pieejas apraksts (Education for modern literacy: description of the teaching/learning content and approach). Riga: VISC. Retrieved from http://www.izm.gov.lv/images/aktualitates/2017/Skola2030Dokuments.pdf (in Latvian)

28. Walsh M. (2010). Multimodal literacy: What does it mean for classroom practice? Australian Journal of Language and Literacy, 33(3), 211-239. Retrieved from https://www.alea.edu.au/documents/item/63\%20\%5B27 